\title{
An Alternative Account of the Populist Backlash in the United States: A Perspective from Turkey
}

Berk Esen, Bilkent University

Şebnem Yardımcı-Geyikçi, Hacettepe University

ABSTRACT Scholars tend to assume that consolidated democracies are free from the global retreat of democracy due to their strong institutions and economic development. Yet, populist forces that challenge the liberal democratic model have started to increase their support even in Western countries. However, in no country has democratic backsliding taken scholars by more surprise than in the United States. This article addresses the question of how a populist figure like Donald Trump managed to win the presidential election and subsequently undermined the democratic institutions in one of the world's oldest democracies. We contend that the upsurge of populist leaders in contemporary Western democracies resulted from the political establishment's failure to juggle responsiveness and responsibility simultaneously. In addition to our discussion of American politics, we draw parallels with the Turkish case to demonstrate our causal argument and offer suggestions on how to reverse democratic backsliding in the United States.

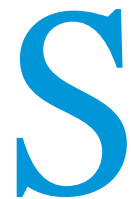

ince the end of the Cold War, an increasing number of democratic regimes have failed at the hands of popularly elected leaders rather than through coups or insurgencies. Accordingly, populist leaders who initially came to power via free elections undermined institutional checks on their power, exerted control over the media and civil society, and targeted opposition forces to reduce the chances of losing an election. This led to the rise of electoral authoritarian regimes with varying degrees of competitiveness (Levitsky and Way 2010; Schedler 2006). Until recently, however, scholars assumed that Western countries would be able to circumvent this global retreat of democracy as a result of their strong institutions, rule of law, and economic development (Diamond 2015). Yet, popular support for right-wing populist leaders with authoritarian tendencies has increased in several Western democracies, including France, Italy, and the Netherlands (Foa and Mounk 2016; Kelemen 2017). In light of these developments, scholars have begun to speculate that we have reached "an inflection point," at which even these consolidated democracies may be in danger of backsliding (Norris 2017).

Berk Esen is assistant professor of international relations at Bilkent University, Ankara, Turkey. He can be reached at berk.esen@bilkent.edu.tr.

Şebnem Yardımcı-Geyikçi is assistant professor of politics at Hacettepe University, Ankara, Turkey. She can be reached at sebnemyardimci@gmail.com.
In no country has democratic backsliding taken scholars by more surprise than in the United States, where Donald Trump was elected president in November 2016. Despite lacking both political experience and a consistent ideology, Trump managed to appeal to a core base of Republican voters using highly divisive rhetoric against his opponents. Given his outsider status, populist discourse, and unorthodox campaign style, Trump's election resembles the rapid rise of authoritarian-minded populist leaders in unconsolidated democracies, such as Turkey, Hungary, the Philippines, and Venezuela (Esen and Gümüşçü 2016; Sedelmeier 2014). Indeed, his election demonstrates that not even advanced democracies with strong institutional checks and balances are immune to the threat of authoritarian populism (Rohac, Kennedy, and Singh 2018). As such, comprehending the causes of democratic backsliding and the mechanisms by which this process has taken place in the previously mentioned countries may shed light on the trajectory of American democracy.

In their recent book, Levitsky and Ziblatt (2018) offered an elite-based scenario for reversing democratic backsliding at the hands of authoritarian populists such as Trump but failed to explain why these leaders achieve political success in the first place. Scholars generally attribute Trump's election to his success in adopting an identity-focused framing on wedge issues (e.g., immigration) at a time of rising ethnic and racial polarization (Weinschenk 2018). Noting the racialization of US politics, for 
instance, Sides, Tesler, and Vavreck $(2017,35)$ described the 2016 election as "the manifestation of the country's broader identity crisis." Although some erroneously claimed that the growing size of minority groups would create a "post-racial America," Trump played into the fears and resentments of white, non-collegegraduate voters who were distressed by the rise of multiculturalism (Hooghe and Dassonneville 2018). According to MacWilliams (2016), Trump activated authoritarian voters with his portrayal of various groups including immigrants and Muslims as threats to the United States. Meanwhile, others highlighted the role of gender bias and patriarchy as factors that increased resentment against Hillary Clinton, especially among white, middle-aged voters (Filipovic 2016). Although they explained the outcome of the 2016 presidential election, these studies neglect to account for the institutional mechanisms behind Trump's election and the ensuing democratic backsliding. This article provides a party-politics view of how-in one of the world's oldest democracies-a populist figure like Trump managed to win the presidency and then began to undermine democratic institutions.

We address this primary question by using the general theory of party government, which suggests that parties should be responsive to voter preferences and also act responsibly in policy making once they are in office (Birch 2007). We contend that the upsurge of populist leaders in contemporary Western democracies resulted from the political establishment's failure to juggle these two tasks simultaneously. In particular, by focusing on governing from the center, mainstream parties caused some constituencies to feel disenfranchised, especially during times of crisis. Perceiving their elected officials as unresponsive to their concerns and opinions, voters turned to populist alternatives. However, rather than solving these voters' problems, this shift intensified the representation crisis because populist figures focus on responsiveness at the expense of responsible rule. In addition to our discussion of American politics, we draw parallels with contemporary Turkey to support our causal argument and offer suggestions to reverse democratic backsliding in the United States. the party-government model of representation is legitimized by the premise that political parties would provide both responsiveness and responsibility. As to be expected, this is an ideal case, and the strain between the two has persisted throughout the history of party politics (Bardi, Bartolini, and Trechsel 2014). The paradox is that whereas responsiveness is related to short-run concerns centered around the immediate needs of voters, responsibility pertains more to long-run outcomes because it requires policy makers to be responsible for the interests of the general public (Birch 2007). Mair (2013) asserted that the contemporary problem with Western European democracies is that with the increasing dominance of cartel parties, parties have leaned toward responsibility at the expense of responsiveness. This has led to the emergence of "democracies without demos," thereby creating a crisis of democracy.

Today, Mair's observations have become relevant for the United States, albeit in a different manifestation. In contrast to European cases, in which governments acted responsibly to preserve European integration but failed to respond to the concerns of those excluded by the existing order, the United States under Trump's rule suffers from enhanced responsiveness with limited responsibility. This is the latter stage of the problem, which arises when voters prioritize responsiveness in the political system. However, this challenge to party government can have dire consequences for democracy, particularly when accompanied by growing polarization at both the elite and societal levels. The literature on party politics already has discussed the dangers of intense polarization, such as the intensification of ideological debates, delegitimization of the regime, and collapse of the party system (Dalton 2008; Morlino 1998). However, this literature fails to address the possible dangers that follow populists' rise to power. We posit that when a growing number of voters believe that the political system no longer addresses their concerns, the likelihood that they will vote for populist leaders increases. Following their rise to power, populist figures tend to value responding to their constituencies above all else because they

\section{We contend that the upsurge of populist leaders in contemporary Western democracies resulted} from the political establishment's failure to juggle these two tasks simultaneously. In particular, by focusing on governing from the center, mainstream parties caused some constituencies to feel disenfranchised, especially during times of crisis.

\section{THE PARTY-GOVERNMENT MODEL: A DELICATE BALANCE BETWEEN RESPONSIVENESS AND RESPONSIBILITY}

Eleven years ago, the late Peter Mair diagnosed the malady of European democracies as the growing tension between responsiveness and responsibility (Mair 2008). Whereas responsiveness refers to the tendency of governments to respond to the demands and wishes of voters, responsibility requires acting prudently in policy making and considering the wider electorate (Birch 2007; Mair 2009). Accordingly, "a government will be regarded as irresponsible if its policies, however popular at the time they are formulated, proved to be imprudent or inconsistent in the long run" (Birch 2007, 140). Responsible government is expected to respond not only to the partisan demands of its narrow constituency but also to the needs of the general public. Mair (2008) argued that perceive political competition as a zero-sum game. This pushes them to ignore the concerns of opposition voters-and even dismiss the opposition's legitimacy-thereby creating the basis for authoritarian leadership. Those who voted for them, conversely, care about neither the authoritarian character of the regime nor the long-term costs to the public good, as long as these strongmen remain responsive. We contend that this is the primary mechanism through which authoritarian populists legitimize their attacks on democratic institutions in the perception of their constituencies.

This is what has occurred in the contemporary United States. As shown in figure 1, the gradual decline in trust in government reached record low levels during the Obama presidency, particularly among conservative Republicans. Although political 
disaffection is prevalent among Republicans and Democrats alike, conservative Republican voters seem to be the most dissatisfied segment of society: an average of only $11.5 \%$ has expressed trust in the government since 2008. It is clear that these voters believe the political system has not met their expectations regarding say, this raises the cost of losing power not only for incumbents but also for their supporters. Under such conditions, strong men start to attack democratic institutions to maintain their hold on power and gain the consent of their constituents for their antidemocratic behavior. Examples in the case of Trump's

\section{In contrast to European cases, in which governments acted responsibly to preserve European integration but failed to respond to the concerns of those excluded by the existing order, the United States under Trump's rule suffers from enhanced responsiveness with limited responsibility.}

responsiveness to their concerns and demands. Indeed, Trump's political success is based on his ability to appeal to white, non-college-graduate, middle-aged voters, who felt neglected and underrepresented for a long time (Fukuyama 2016). The slogan "Make America Great Again!" was crafted to remind these people of "a mythic past" when they benefited from the political system (Tharoor 2018). In other words, Trump's rhetoric clearly draws on enduring resentments in American society and aims to tap into a shared animosity against "others." Trump's anti-Muslim stance, which was manifested in the form of a travel ban; his efforts to end the Deferred Action for Childhood Arrivals (DACA) program; and his defense of white supremacists marching in Charlottesville, Virginia, are all examples of responsiveness to the demands of his voters (Huq 2018). However, responding exclusively to conservative Republicans comes with the cost of overlooking and even excluding other constituencies, such as minorities.

Although it consolidates his own support, Trump's approach alienates other voters. When political competition is loaded with collective animosity, it tends to become a zero-sum game that hinders tolerance and dissent among those opposed. Needless to

Figure 1

Trust in Government by Party and Ideology

$\%$ who trust the govt in Washington always or most of the time 100

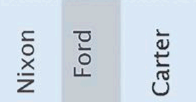

75

$$
75
$$

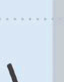

50

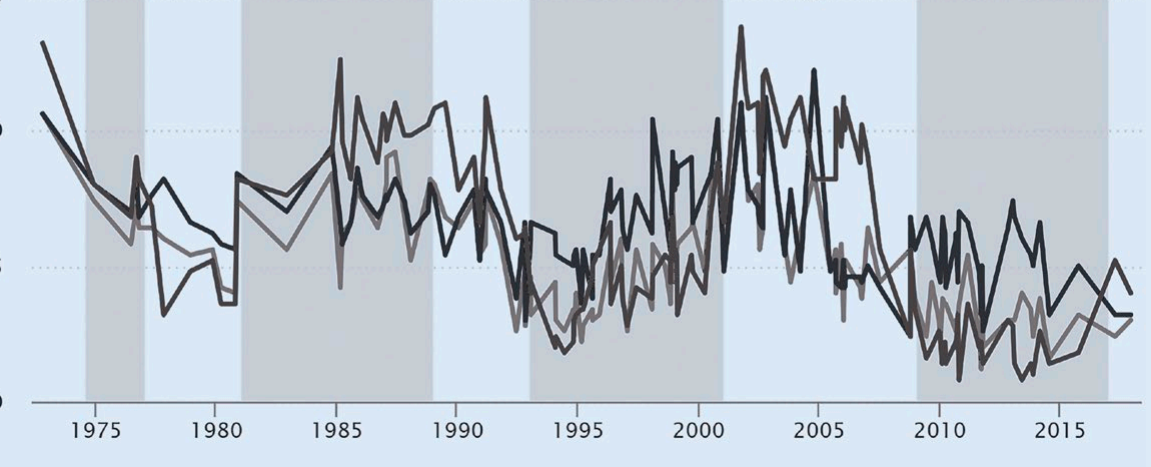

- Conservative Rep/Lean Rep

- Cons-Moderate Dem/Lean Dem

- No partisan lean

Source: Pew Research Center, available at http://www.people-press.org/2017/12/14/public-trust-in-government-1958-2017/
United States include the White House's interference in federal investigations regarding possible Russian involvement in the 2016 elections and his portrayal of the judiciary as the "deepstate Justice Department" and journalists as the "enemy of the American people" (Kristof 2018). Moreover, Trump's attempts to co-opt civil service through partisan interventions runs the risk of weakening the independence of state institutions (Huq 2018). Such disrespect for democratic norms and rules at the presidential level weakens the strength of these institutions over time and reinforces the view that they are negotiable.

We assert that in polarized party systems, the excessive push toward responsiveness at the expense of responsible rule is dangerous for the survival of democracy. As evidenced in figure 2, the ideological gap between Republicans and Democrats has widened significantly during the past 20 years, which indicates a high level of polarization. Polarization not only provides populists with suitable conditions to gain power; it also allows them to reinforce that power by reminding voters that their fate is linked to the regime's survival. This point is evidenced in Trump's stable approval ratings. The most recent polls suggest that whereas an average of $84 \%$ of Republicans approve of Trump's performance, only $7 \%$ of Democrats share this view (Dunn 2018).

\section{WHAT THE INFAMOUS}

\section{EXAMPLE OF TURKEY UNDER}

ERDOĞAN SUGGESTS FOR THE UNITED STATES UNDER TRUMP

Similar to the US case, Turkish democracy recently has been in crisis under the rule of the Justice and Development Party (Adalet ve Kalkınma Partisi [AKP]). When the party first came to power in 2002, Turkey was suffering from a lack of effective party government. During the tumultuous 1990s-which were characterized by instability, clientelism, and corruption-the ruling elites could provide neither responsiveness nor responsibility. Given declining voter confidence in 
mainstream parties, the newly established AKP originally aspired to serve in both roles. In this sense, the AKP's initial rise to power differed from that of Trump because the party promised to respond to the concerns of the general electorate by crackdown on its own citizens (Yardımc1-Geyikçi 2014). Both during and after the Gezi protests, Erdoğan gained consent for his repressive policies from AKP voters by manipulating political and sectarian divisions in society.

\section{Democratic backsliding in Turkey intensified after Erdoğan's election as president in August 2014. Following his election by popular vote, Erdoğan turned his attention to acquiring vast executive powers with limited oversight and accountability.}

addressing the economic crisis. Despite its Islamist origins, the AKP initially moderated its policy agenda and discourse to appease its secular critics while managing the economy effectively to expand its popular base (Hale and Ozbudun 2009). These steps were hailed by most analysts at the time as responsible government. However, as the party gradually increased its electoral strength, it began to focus more on playing a representative role for conservative groups that had felt excluded under the secular regime; in so doing, it moved away from responsible government.

Especially after winning reelection in 2007 with nearly half of the electorate's support, the AKP began to capture state institutions and impose its hegemony over society as a whole. With the 2010 referendum, the AKP captured the judiciary and used dubious trials to purge its opponents from the military and state bureaucracy (Esen and Gümüşçü 2016). From this point on, the AKP shifted its strategy to retaining a weak majority by playing on the division between its supporters and the rest of the electorate. Disregarding demands of the secular population, for instance, the government adopted a religious agenda in both societal and state affairs. From taxes to education policy, the ruling AKP imposes its religious views in a wide range of areas despite mounting criticism from secular groups. When the discontent over these shifts grew into popular protests in the summer of 2013, the government responded with a massive
Democratic backsliding in Turkey intensified after Erdoğan's election as president in August 2014. Following his election by popular vote, Erdoğan turned his attention to acquiring vast executive powers with limited oversight and accountability. He achieved this goal when the parliament amended the constitution to introduce a strong presidential system that erodes horizontal accountability and violates the principle of separation of powers, thereby paving the way to an increasingly authoritarian regime. We contend that regime change in Turkey was a direct result of extreme responsiveness-an overwhelming majority of AKP voters approved the new presidential system in the 2017 referendum due to their personal loyalty to President Erdoğan (Esen and Gümüşçü 2017).

This point is indeed what makes the Turkish case particularly comparable to that of the United States. As the previous discussion illustrates, Trump has chosen to respond to his own constituency at the expense of rest of the electorate. However, as was the case in Turkey, Trump's focus on responsiveness endangers the prospect of responsible government in the United States. One clear example is Trump's nomination of Judge Brett Kavanaugh to replace retiring Judge Anthony Kennedy and his subsequent confirmation by the Senate. With a conservative judicial record, the choice of Kavanaugh clearly demonstrates that Trump preferred to respond to his base by pushing the court further to the right (Al Jazeera 2018). Indeed, Trump's

\section{Distribution of Democrats and Republicans on a 10-item Scale of Political Values}

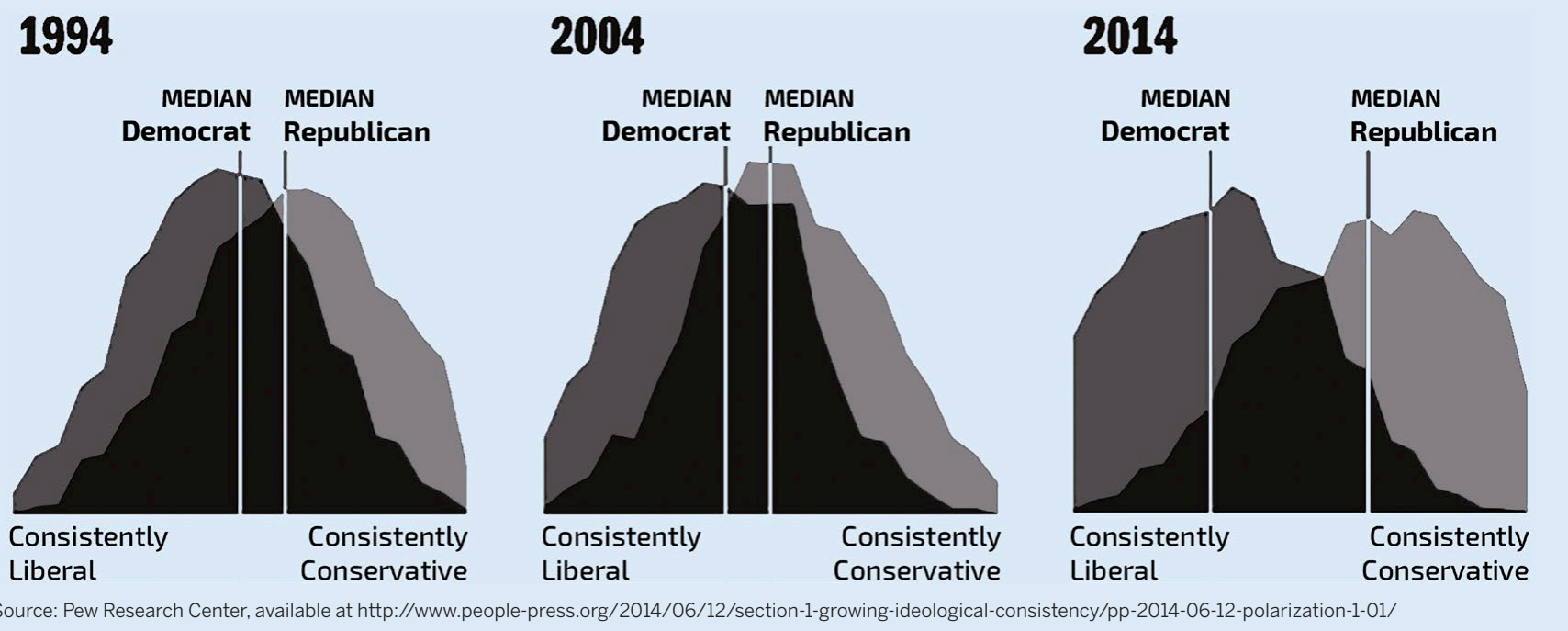


choice has given the Supreme Court a clear conservative majority-possibly for decades to come. Needless to say, given Kavanaugh's partisan attitudes during the hearings (New York Times 2018), this move risks the impartiality of the Supreme Court in the perception of the liberal constituency while satisfying conservative voters. The rapid pace of democratic backsliding in Turkey under Erdoğan demonstrates what happens when pro-government voters ignore attacks on democratic institutions as long as their demands are met. In this scenario, polarization intensifies, accountability erodes, and the system ultimately fails to represent the electorate at large. This has the potential to threaten the future of American democracy.

\section{CONCLUSION}

This article offers a causal argument derived from the literature on European politics to account for Trump's surprising election as President of the United States. In light of Turkey's democratic backsliding, we suggest that the US political establishment's failure to balance the demands of responsibility and responsiveness in recent years fueled a populist backlash that catapulted a populist leader with authoritarian tendencies to power. In highly polarized societies such as the contemporary United States, populist leaders can consolidate their constituency by intensifying the ethnic, religious, and class cleavages, which in turn transforms democratic politics into a zero-sum game. Basing his power on vertical accountability, Trump has withstood democratic pressures from the media and civil society by responding to the needs and grievances of his constituency while showing limited tolerance toward his opponents.

We do not consider it likely that American democracy will collapse in the near future. Nevertheless, the Turkish case sheds light on where the United States may be headed under Trump's rule and what can be done to reverse the trend. Just as the AKP's inclusion in the mainstream political system did not moderate its Islamic agenda, Trump's election will not push his positions toward the center. Therefore, democratic forces in the United States must remain constantly vigilant against the prospect of backsliding under Trump. His critics should refrain from taking any steps that could further polarize American society. Although Trump may be a dangerous demagogue, some of his supporters have valid political concerns and economic grievances that opposition politicians must address at some level to win elections.

One way of limiting Trump's damage to democratic institutions is to take his agenda seriously. His critics should hold Trump accountable for his unmet campaign promises to persuade as many of his supporters as possible. That said, democratic institutions can survive Trump's attacks only if there is sufficient popular support for them in the long run. Democratic forces in the United States should use every opportunity to publicly defend and popularize checks and balances in the system. Even then, these institutions can only slow-but not stop-Trump's polarizing declarations, partisan appointments, and executive decrees. Should Trump remain popular, democratic backsliding might become a genuine threat for the United States. Democratic forces should establish broad coalitions to counter Trump's attacks on civil society and the media. We know from other cases that a coalition of democratic forces has significant power to turn the tide in favor of democracy and defeat autocrats (Bunce and Wolchik 2011). Monitoring and publicizing Trump's authoritarian traits may weaken his popular legitimacy and limit the damage that he can inflict on US democracy. After all, these strong leaders heavily rely on their popular support, and they overvalue responsiveness at the expense of responsibility.

\section{ACKNOWLEDGMENTS}

The authors thank Yüksel Yasemin Altıntaş for assistance in the preparation of the figures and anonymous referees for their valuable comments on previous drafts.

\section{REFERENCES}

Al Jazeera. 2018. "Trump Picks Brett Kavanaugh for US Supreme Court: What to Know." July 10. Available at www.aljazeera.com/news/2018/o7/trump-supremecourt-nomination-180709104541613.html.

Bardi, Luciano, Stefano Bartolini, and Alexander H. Trechsel. 2014. "Responsive and Responsible? The Role of Parties in Twenty-First-Century Politics." West European Politics 37 (2): 235-52.

Birch, Anthony. 2007. The Concepts and Theories of Modern Democracy. London: Routledge.

Bunce, Valerie J., and Sharon L. Wolchik. 2011. Defeating Authoritarian Leaders in Postcommunist Countries. New York: Cambridge University Press.

Dalton, Robert J. 2008. “The Quantity and the Quality of Party Systems: Party System Polarisation, its Measurement, and its Consequences." Comparative Political Studies 41 (7): 899-920.

Diamond, Larry. 2015. "Facing up to the Democratic Recession." Journal of Democracy 26 (1): 141-55.

Dunn, Amina. 2018. “Trump's Approval Ratings So Far Are Unusually Stable—and Deeply Partisan." Pew Research Center, August 1. Available at www.pewresearch. org/fact-tank/2018/o8/o1/trumps-approval-ratings-so-far-are-unusually-stableand-deeply-partisan.

Esen, Berk, and Şebnem Gümüșçü. 2016. "Rising Competitive Authoritarianism in Turkey.” Third World Quarterly 37 (9): 1581-606.

Esen, Berk, and Sebnem Gümüșçü. 2017. "A Small Yes for Presidentialism: The Turkish Constitutional Referendum of April 2017." South European Society and Politics 22 (3): 303-26.

Filipovic, Jill. 2016. "The Revenge of the White Man.” Time Magazine, November 10. Available at http://time.com/4566304/donald-trump-revengeof-the-white-man.

Foa, Roberto Stefan, and Yascha Mounk. 2016. "The Democratic Disconnect." Journal of Democracy 27 (3): 5-17.

Fukuyama, Francis. 2016. "Trump and American Political Decay: After the 2016 Election." Foreign Affairs, November 9. Available at www.foreignaffairs.com/ articles/united-states/2016-11-o9/trump-and-american-political-decay.

Hale, William, and Ergun Ozbudun. 2009. Islamism, Democracy and Liberalism in Turkey: The Case of the AKP. London: Routledge.

Hooghe, Marc, and Ruth Dassonneville. 2018. "Explaining the Trump Vote: The Effect of Racist Resentment and Anti-Immigrant Sentiments." PS: Political Science \& Politics 51 (3): 528-34.

Huq, Aziz. 2018. "Under Trump, the United States Has Joined the Sad Roster of Backsliding Democracies." Vox, January 30. Available at www.vox.com/the-bigidea/2018/1/30/1695068o/democratic-backsliding-loss-of-democracystate-of-union-authoritarian-trump.

Kelemen, R. Daniel. 2017. “Europe's Other Democratic Deficit: National Authoritarianism in Europe's Democratic Union." Government and Opposition 52 (2): 211-38.

Kristof, Nicholas. 2018. "Trump's Threat to Democracy." New York Times, January 10. Available at www.nytimes.com/2018/01/10/opinion/ trumps-how-democracies-die.html.

Levitsky, Steven, and Lucan Way. 2010. Competitive Authoritarianism: Hybrid Regimes after the Cold War. Cambridge: Cambridge University Press.

Levitsky, Steven, and Daniel Ziblatt. 2018. How Democracies Die. New York: Crown.

MacWilliams, Matthew C. 2016. "Who Decides When the Party Doesn't? Authoritarian Voters and the Rise of Donald Trump." PS: Political Science $\mathcal{E}$ Politics 49 (4): 716-21.

Mair, Peter. 2008. “The Challenge to Party Government.” West European Politics 31 (1-2): 211-34.

Mair, Peter. 2009. “Representative versus Responsible Government.” Max Planck Institute for the Study of Societies Working Paper 09/8:1-19.

Mair, Peter. 2013. Ruling the Void: The Hollowing of Western Democracy. London: Verso Books. 
Morlino, Leonardo. 1998. Democracy between Consolidation and Crisis: Parties, Groups, and Citizens in Southern Europe. Oxford: Oxford University Press.

New York Times. 2018. "The Senate Should Not Confirm Kavanaugh." October 3. Available at www.nytimes.com/interactive/2018/10/03/opinion/ kavanaugh-law-professors-letter.html.

Norris, Pippa. 2017. "Is Western Democracy Backsliding? Diagnosing the Risks." Harvard Kennedy School Faculty Research Working Paper Series. March.

Rohac, Dalibor; Liz Kennedy, and Vikram Singh. 2018. "Drivers of Authoritarian Populism in the United States." Center for American Progress. Available at www. americanprogress.org/issues/democracy/reports/2018/05/10/450552/driversauthoritarian-populism-united-states.

Schedler, Andreas (ed.). 2006. Electoral Authoritarianism: The Dynamics of Unfree Competition. London: Lynne Rienner Publishers.
Sedelmeier, Ulrich. 2014. "Anchoring Democracy from Above? The European Union and Democratic Backsliding in Hungary and Romania after Accession." Journal of Common Market Studies 52 (1): 105-21.

Sides, John, Michael Tesler, and Lynn Vavreck. 2017. “The 2016 US Election: How Trump Lost and Won." Journal of Democracy 28 (2):34-44.

Tharoor, Ishaan. 2018. “The Political Trend That's More Important Than 'Populism.” Washington Post, February 16. Available at www.washingtonpost.com/news/ worldviews/wp/2018/02/16/the-political-trend-thats-more-important-thanpopulism/?utm_term $=$. bb6c4f $7 \mathrm{df} 7 \mathrm{co}$.

Weinschenk, Aaron C. 2018. "That's Why the Lady Lost to the Trump: Demographics and the 2016 Presidential Election." Journal of Political Marketing 1-23, 10.108o/15377857.2018.1478657

Yardımc1-Geyikçi, Şebnem. 2014. "Gezi Park Protests in Turkey: A Party Politics View." The Political Quarterly 85 (4): 445-53. 